\title{
Principal's Leadership In Developing Primary School Students Character
}

\author{
Sri Marmoah
}

\begin{abstract}
This study aims to analyze the principal's efforts in building student character, the role of the teacher to assist the principal in building the character of students, and the efforts of principals, teachers, and committees to overcome obstacles in building student character. The study used a qualitative approach. Data was gathered through interviews, observation, documentation, and questionnaire. Data were analyzed by reducing the data, presenting data, and inferring data. The findings obtained in this research cover a wide range of topics: (1) the principals are directly involved in building the students' character through a variety of school activities; (2) the principals oversee the development of student character directly; (3) principals and teachers work together to build the character of students through the integration of the character values with the teaching material; and (4) lack of supporting infrastructure and the teachers who are not cooperative become the obstacles faced by a principal in building the student's character. Based on the results, the researcher recommends that school can collaborate with school committees, and other school residents to develop students character and integrate character building with subjects taught at the time of teaching and other activities.
\end{abstract}

Keywords: Leadership; Head Master; Character

\section{INTRODUCTION}

Character education is currently the topic of discussion for education officials, especially secondary education and basic education. Strengthening the character in each lesson has been promoted in various levels of education. Implementation of strengthening and building the character of students listed in the Republic of Indonesia Law Number 20 of 2003 Article 3 concerning the National Education System which states that National Education functions to develop the character and potential of students so that students have a fear of God Almighty, noble, healthy, knowledgeable, skilled, creative, independent, become a democratic citizen, and responsible [1].

The educational goals stated in the law, it seems that there must be intensive and exclusive actions to build character to become qualified human beings. Character education is needed to prepare the millennial generation, which will later become the pioneer of the nation's awakening and development. Therefore, the need for special and rapid handling of education officials so that the aim of national education can be crystallized immediately.

One of the people who have a big influence on making changes intensely with students is educators and education

Revised Manuscript Received on April 19, 2019.

Sri Marmoah, Teacher Training and Education Faculty, University of Sebelas Maret, Surakarta, Indonesia

(email: marmuah@staff.uns.ac.id) in schools. Principals, as managers in each school have great authority to declare that the school is ready to implement character education. The principal has an important role in the application of character building for students in the school, especially in coordinating, regulating, and harmonizing all available educational resources. Leadership is defined broadly as a process of influence that influences the interpretation of events to achieve goals, maintains cooperative relations, and work of teams or organizations [2].

The school must have a good team. The principal can collaborate with the teacher and the school committee. Besides the principal, teacher manipulates the main role in the development of student character because they have the most frequency of meetings with students. The committee as the intermediary of the school with the parents of students is also an active supporter to realize the program. The achievement of student character development is faster and in line with expectations when all of them have collaborated.

Unfortunately, there are often social inequalities that do not reflect the character of the Indonesian people, especially the character as students. This is reflected in acts of violence, anarchism, bullying, social conflict, and student impoliteness in language. A small example of students in a school that indicates the low character of students is the use of regional language when talking to the teacher. The low level of student character education is evidenced by research conducted by Bulach \& Butler [3] which states that assessment is not a measure of the success of a program because many programs from schools regarding character education are not in accordance with students necessary.

The problems must be overcome by the leadership of principals, teachers, and the role of school committees. If there is no intensive action to overcome the problem, moral degradation and national character will be possible. The loss is happening from the polite of young people to the older ones. That, of course, must be immediately overcome with several structured efforts. Strategies or efforts can be made, namely the development of the character of students studied in depth with the help of the principal's leadership, as well 
as the role of the teacher and school committee.

Leadership is defined as the style of the headmaster's role in imaging and creating a positive atmosphere for his environment. In the context of the scope of education, leadership is held by the principal as manager of a school. The principal is the highest leader in the internal school. Principals are managers who can influence the entire school community to build the quality of education in a democratic and participatory manner [4]. The principal has the character and style to play the role and authority attached to him to optimize the duties and functions of all human resources in his school. The Ministry of National Education states that there are 18 values developed in character education, namely: religious, honest, tolerance, discipline, hard work, creative, independent, democratic, curiosity, national spirit, love for the country, respect for achievement, friendship/communication, peace of mind, love to read, care for the environment, social care, and responsibility [5]. Educational units can determine the values to be developed. The selection is adjusted to the conditions and interests of the school, but it is recommended to develop those that are essential, simple, and easy to implement.

Instructional leadership can be a powerful way to influence schools in developing student character. Principals are teachers who work as leaders from various aspects of cognitive, affective, and psychomotor students [6]. In addition, Robinson, Jones, \& Hayes [2] explains "many things, and character education has become a general term for many non-related programs, such as learning service programs, moral education, and civic education".

However, the principal is not the only principal regulator of the school. The principal needs to consider proposals from the teacher and the school committee as partners in his work. The role of the teacher and committee also provides a good break-even point for the progress of the school. Moreover, teachers can meet more frequently with students. The school committee also introduces various difficulties faced by schools to find solutions together with parents of students, and vice versa.

Pearson \& Nicholson [7] argue that the specific role of school personnel, such as counselors, administrators, and teachers, also plays an important role in implementing character education programs. The role played by these people in their implementation can be different for each school. The role of community members to exemplify justice, respect, and caring [8]. The school committees and stakeholders have a role to play in evaluating school character education programs because they interact directly with students [9]. The several studies show that character building developed through school culture has proven to provide good results, such as: caring for cleanliness, beauty, and tidiness; obedience and mutual respect; have a good relationship with family; honest and responsibility; maintain togetherness; neat document archiving; school participation and involvement is very good; and adequate education infrastructure [10]. Therefore, character development in IT As Salam has been done through planning, implementing, and evaluating well-conceptualized teaching disciplines [11]. Meanwhile, the success of every moral education program is crystallized in three components: family, school, and community but school is considered the main basis of character education. The school character education program will succeed if the interaction and cooperation between family, community, and school go well [12].

This research is different from previous research. Some previous studies only discussed the implementation of character education in schools alone without discussion of the important role of school principals. The role of the principal and teacher is a role unit that must coordinate and work together so that the planned character education can be realized. This research is also not limited to their role, but there is an involvement of school committees, which relate directly to student guardians. The study focused on three problems, namely: the principal's leadership efforts in building student character, the role of the teacher to assist the principal in cultivating the character of students, and how principals, teachers, and school committees overcame obstacles in building character students in primary school.

\section{METHODOLOGY}

This study utilized a qualitative approach that aims to examine the problems and obtain a more profound meaning in accordance with background research. The study begins with an initial observation of the research site, intended to identify where the research is conducted clearly. The researchers begin with the assumption that the context itself and the researchers are closely related to contextual factors [13]. The invention the subject of the study using a purposive sampling technique, namely the determination of the sample with a particular consideration. The subject of the study are the headmaster, religious teacher, civic teacher, classroom teachers, SDN 1 Kleco, Surakarta, and other sources necessary were involved directly or indirectly in research. The key informants in this research are the headmaster, teachers, and students. The research data collected using three main techniques, namely observation, interviews, documentation study, and questionnaire. The data analysis procedure that the author traveled in this study consists of the following four steps, specifically: data reduction, presentation of data, and verification. Submit your manuscript electronically for review.

\section{RESULT AND DISCUSSION}

A. The Efforts of Principal Leadership in Building the Students' Character.

An explanation of the principal's leadership became the main object of this research begins with some opinions expressed the informant regarding the leadership of the headmaster. The results of observation and interview for three months in the school environment show that the leadership style of the principal became a major force on the behavior and character building of students, either directly or indirectly. The school's success in achieving the objectives that have been set out in the vision and mission, especially in the characters building their students will depend largely on how the principal institution in the lead of the school. The principals' management in building 
students' character, which is as follows.

1. The Principal Gives the Advice of Building Character for The Students at The Time of The Flag Ceremony Held on Every Monday

As defined by the (ES) vice principal as follows:

"The principal always gives direction to students at the time the Builder of the ceremony. He often delivered things concerning discipline, compliance, delinquency, and invites students to love the environment. He often delivered in the order that the students always do: turn on the mobile phone alarm to wake up in the morning, pray, learned after the dawn, then showered and went to school".

The result of interviews is clear that the principal is always building the character of the students personally, especially during the implementation of the flag ceremony on Monday. The advice always is given with the expectation that the students of SDN Kleco 1 good character and personality. The principal can do something to develop the character of students through school culture, one of which is the flag ceremony, which is always held on Monday morning [14].

2. The Principal Gives Advice of Building Character for The Students at The Time of The Flag Ceremony Was Carried out on a Major National Daily

The result of interviews with (ES) the headmaster explained that major national day ceremonies are often held in the school such as Independence Day, the day of national education, the youth Oath Day, a day of the divine power of Five Principles, and the big day other national. The headmaster (ES) submits:

"The principal always gives direction to students at the time the Builder of the great Memorial Day ceremonies nationwide. The anniversary of the Day of national education principals gives direction to let the students discipline and actively in learning both in the classroom and at home ".

The results of the interview above show that in any event, the principal always advises students so that being of good character and personality. National days are a tradition that is often done at school. Students are trained to care and not forget the services of national heroes by celebrating national holidays [4].

3. The Principal Advises on building character for the student at The Time of Ceremony the Islamic Great Day

The results of the interview with teachers of Islamic religion (NB) SDN Kleco 1, explains:

"Development of character is often done by the principal at the time of celebrating the big day Islam as the Prophet Muhammad and Isra Mi'raj. Celebrating of the Maulid Prophet Muhammad to convey the principal so that the students have always been devoted to God and can emulate behavior from the noble Prophet Muhammad. Isra' Mi'raj commemorates Prophet Muhammad delivered a school principal in his speech that the students are diligent in performing prayers five-time ".

In another chance (ES) vice principal explained that:

"at the time commemorate the large Islamic as the birth of the prophet and Isra' Mi'raj the prophet Muhammad saw he often convey in his speech on development character to the students like the students have to believe in power and the only one God and Muslims and adherent to command the most power and away from all he forbids.

On this occasion, principals and teachers allowed tolerate to the students who did not Muslim did not attend the commemoration day of Islam. As expressed by religious education teachers as follows: as a form of tolerance among religious communities. Religious differences will train tolerance and mutual respect among each other so that everyone will respect others [15].

4. The Principal Build Character of Students at the Time of a Routine Agenda In Month of Ramadan

The public primary school should implement the activities of the fasting month of Ramadan at the beginning of the Islamic month of Ramadan. The activities carried out by a recitation of al-Quran, competition talk religion, and the contest of azan. Islamic education teachers said:

"on that occasion, the school principal gives the word to his remarks in dialectic in the opening act in the fasting month of Ramadan. He revealed that as one who believes and devotion to the lord and obliged to give fasting month".

This program will have an impact on student character through curriculum development. It is necessary for educators to help children broad positive character so that they will have good character [16]. Ramadan activities also affect the character of students because they will be more respectful and tolerant.

5. The principal Gives the Development Character of Students through Supervision Directly to Students at Rest

A break is a time the students for free of attachment time learning. In this activity the school principal who had the oversight of directly for students who flouted the rules. It shows when he is watching the students are resting. He said:

"The break times, I monitor the students who are resting; this is doing on my own because I saw a lot of the students who buy food outside the school because canteen is in school insufficient. To date, they freely buy food outside the school, causing students to do they violate the school, like garbage in public places so that garbage scattered everywhere. This condition makes me be directly involved and admonish for students, make to love the environment, and makes school cleaner".

Besides through observation and interview, researcher to digs information about values development education characters in the school was reviewed from behavior head school through a questionnaire. There are several values measured as owned characters head the school, namely: tolerance, democratic, disciplined, work hard, creative, responsible, and friendly, appreciates the achievement, confidence, and assertive. The results can be shown on table 1. 
International Conference on Recents Advancements in Engineering and Technology (ICRAET-18) |15th and 16th March 2019|Siddhartha Institute of Technology \& Sciences, Telangana, India.

Table 1. The Principal's Leadership

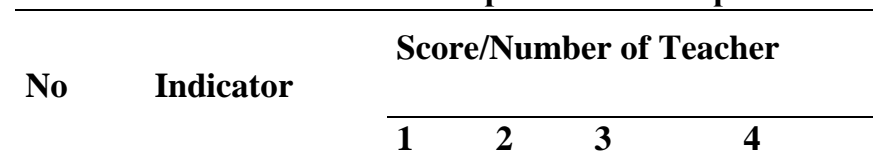

$1 \quad$ Tolerance

a. The

$7 \quad 5$

principal opens

up criticism

and

suggestions

$\begin{array}{lllll}\text { b. The } & - & - & 6 & 8\end{array}$

principal

always work

together

Percentage

$46,5 \%$

$46,5 \%$

\begin{tabular}{|c|c|c|c|c|c|}
\hline \multirow[t]{4}{*}{2} & Democracy & & & & \\
\hline & $\begin{array}{l}\text { a. The } \\
\text { principal gives } \\
\text { freedom of } \\
\text { creation }\end{array}$ & - & - & 4 & 10 \\
\hline & $\begin{array}{l}\text { b. The } \\
\text { principal } \\
\text { supports ideas } \\
\text { to develop the } \\
\text { class and } \\
\text { potential of } \\
\text { students }\end{array}$ & - & - & 3 & 11 \\
\hline & Percentage & - & - & $25 \%$ & $75 \%$ \\
\hline
\end{tabular}

3 Discipline

a. The

5

9

principal

comes early

b. The

principals wear

uniforms

according to

the rules

Percentage

$18 \%$

$82 \%$

$4 \quad$ Hard work

a. The

2

principal

checks the

class

administration

regularly

b. The

headmaster

arranges a

structured

schedule for

class

administration

Percentage

$-$

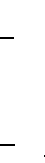

a. The

principal can

use various

learning media

b. The
principal can
modify the

learning

evaluation tool

Percentage

$46,5 \% \quad 50 \%$

$6 \quad$ Responsible

a. The

principal is

responsible for

implementing

the school

program

b. The

principal

supervises

school

activities

regularly

Percentage

1

13

Friendly

a. The

principal

establishes

good

communication

b. The

2

principal greets

teachers and

students

Percentage

$10,5 \%$

$89,5 \%$

$8 \quad$ Appreciate the

achievement

$\begin{array}{lllll}\text { a. The } & 2 & 10 & 2\end{array}$

principal gives

reward

b. The

principal

facilitates

teachers and

students

Percentage

$7 \% \quad 39,5 \%$

$53,5 \%$

$9 \quad$ Confidence

a. The

principal is

doing a good

job 
b. The

1

principal has a

firm stance

Percentage

$21,5 \%$

$78,5 \%$

$10 \quad$ Assertive

a. The

3

principal

prohibits the

use of

cellphones

b. The

1

principal gives

a sentence that

violates the

rules

Percentage

$14 \%$

$86 \%$

\begin{tabular}{lllll}
\hline Total & - & 2 & 68 & 207 \\
\hline Percentage & - & $\begin{array}{l}0,72 \\
\%\end{array}$ & $24,55 \%$ & $74,73 \%$ \\
& & & & \\
\hline
\end{tabular}

Based on the above observations, the 10 leadership characters possessed by the principal are as follows: $0.72 \%$ of the leadership characters are categorized as group 2 (disagree), $24.55 \%$ of leadership characters are categorized as group 3 (agree), and $74.73 \%$ characters leadership is categorized as group 4 (strongly agree).

B. The Role of Teachers for Helping the Principal in Building Students' Character the school when he capable of affecting others to perform his duty. The results of the interviews of the headmaster that school principals had been constructing of students' character together with teachers.

"I always stress to teachers field of study that when teach the subject matter to integrate the values of character as mandated in the law that implemented through k-13, this report when meeting".

From the results of the interviews mentioned above can be understood that the principal always gave develop character to students by indirect, for example, through teachers. The results of interviews with (NB) Islamic education teachers as follows:

"To the learning process, I always lesson to linking the character by integrating the subject matter to the development of the character. As the examples when I was teaching material on fasting, then I linked the material on discipline. One who is fasting has to discipline time at the time when breaking of fast and during feed must follow the time appointed".

The classroom teacher is the teacher who is given the task to call, process, and resolve all problematic students using several approaches. The approach used is persuasive approaches, psychological, preventive, and repressive. This approach is useful for maintaining good cooperation between the principal and the teacher [17]. In certain cases, the principal directly helps the classroom teacher in problem-solving. For example, a child fighting, come late in
School principals were able to play a role as the leader of

the class, did not work on tasks, and other issues. As expressed by (WK) classroom teacher of V:

"The principal has always helped me given problemsolving rather heavy. For example, children who fight and came late in the class. The principal advises troubled students. If the problem had been done three times, then the principal will invite parents to tell their children's behavior. This is done for students to have a good character".

\section{The Headmaster, Teachers, and School Committee} Overcoming Obstacles in Building Students Character

The ideal principals must be able to act as a leader. A good leader must give attention and formulate achieving the objectives of the organization. Thus, the leader can be interesting members and have the expertise and knowledge more than his group. The school has created rules or code of conduct of the school. This regulation aims to let students have a playbook in following the activities of teaching and learning process so that students can be repressed and delinquency their behavior can be better. It is as expressed by ES as follows:

"The policy conducted by the principal to make the rules of the school together with the teachers, the School Committee, and the parents are very nice. Its impact is becoming more orderly student behavior, discipline students become better, and the school environment is cleaner. This is because students who break the rules will be given punishment by the gaffe".

The existence of rules has made and mutually agreed on schools. After this regulation was made, the headmaster was easier to give punishment to students who violate. The principal stated that the building of student's character has done so that students have good character and can comply with the regulations of the school. A rule is something that every student must obey [16].

The results of interviews stated that the principals recommended many program activities to build student character as follows: as a creativity stage to train students to process waste into products that have artistic value; a day with the doctor to increase students' insight into health; a day with the police to increase students' insight into the importance of traffic safety and the danger of abuse of addictive substances; and sustainable activities aimed at commemorating world environmental day. This activity is able to foster scientific characters that care about the environment, health, and comply with regulations.

The description has attempted to provide students and develop the potential of students through student organizations in schools. It can also bring changes to students in learning. Students will learn democracy directly in organizing though it is limited in scope for the size of primary school students is good enough. Student involvement provides great benefits; namely, students have a commendable character, dare to be leaders, dare to express opinions, accept suggestions and criticisms, tolerance, democratic, respects, responsibility, acts trustworthy, fair, honest, creative, and efficient. The involvement of students in student activities minimizes the occurrence of negative

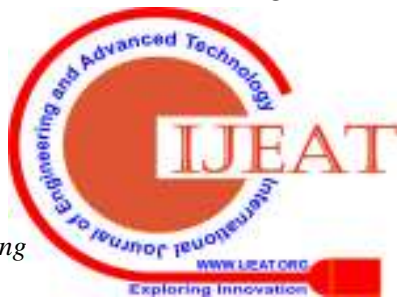


deviations and actions. Therefore, the results of the interview, the principal said:

"In Trisatya and Dasadarma of scouts contain diverse character values. Trisatya contains scout promises, while Dasadarma contains moral provisions for scouts. I try to apply these character values to real actions. The character values that have been applied to students who take part in scout activities include noble values, competing souls, tolerance, mutual respect for others, caring for the environment, caring for others, and spiritual values.

Character building in spiritual values can be observed through prayers together at school for Muslims. Noble values can be observed from students participate in scout training activities. Competing souls can be observed from the students' fighting spirit during training. Tolerance can be observed from the attitude of respecting and the feelings of friends both when deciding something or in competition activities that determine win and lose. Mutual respect for others is observed through patience and does not show pride in training activities. Concern for the environment can be shown from the behavior of students who take training that love cleanliness, they do not litter and collect garbage after the training activities end. The implementation of character education, which contains local values, will support the personal and social life of the community in family, friendship, society, and in nationality to achieve a better life in the future [18].

The obstacles faced by principals in building students' character are as follows: the existence of a teacher who does not help the principal in building the character of students; the number of canteens in the school; inadequate worship facilities at the school; and calling to parents but did not come to the school. Based on the interview with the headmaster, he explained that:

"First, the development of the value of discipline to students is very important, especially the discipline of students when entering the class in the morning. When they enter the class is very much needed cooperation of all parties of the school, it is not enough just security to supervise students but must be called and advised. Second, the canteen available in the school was not sufficient to serve existing students. The number of canteens just three, while the number of students was more. As a result, many students were out of school, and many of their used snacks were scattered. Third, the condition of the Mosque in the school is small. Fourth, some students have problems and need to be presented by parents. The school sends a letter of call to parents to come to resolve the problem. But most parents didn't come to school".

The character of the principal's leadership is important in the implementation of character education. Based on the results of a questionnaire distributed to nine teachers at Kleco 1 Elementary School 1, it was found that the Principal had a good character of leadership. The finding data obtained is $74.73 \%$ indicating strongly agree (4), $24.55 \%$ indicated agree (3), $0.72 \%$ indicates disagreement (2), and $0 \%$ indicates strongly disagree (1). Thus, it can be said that the principal of Kleco 1 Public Elementary School has ten leadership characters in the form of tolerance, creativity, democracy, discipline, hard work, responsibility, friendliness, respect for achievement, independence, and firmness.

Pane \& Patriana [19] revealed that principals need an attitude of responsibility, discipline, firmness, and tolerance that can be integrated with subjects. This attitude can be strengthened through good cooperation between principals, teachers, and guardian students [20]. One form of cooperation is school administration activities. School administration also needs to be evaluated to improve conditions for the better [21]. Principals and teachers must have good competence in their fields. This can be demonstrated through the application of applied learning models or media or learning tools ([14]. The innovative learning model will develop students' independence [1]. Some other things that the principal has shown are good communication. Communication is not limited to the classroom walls, but also covers the school environment and the wider community.

The tenth character value is stated in the education regulation and national minister number 87 of 2017 concerning strengthening character education [5]. The results of the character leadership of the principal can develop the character of students indirectly. Leadership is a capability of persuading others to work together under their direction as a team to accomplish certainly designated objectives. Larry \& Darcia [22] states that education explicitly aims to shape character. Based on the findings of this study, school programs (tradition and school habits) must be able to connect and build the character of students in the school. Bernard et al. [23] explained that learning carried out through school habits and traditions is a means of supporting the development of one's abilities. Someone will be able to express themselves in their lives because things that are expressed are a part that they often do. Character learning will also support children's abilities in managing learning tasks, interaction, problem-solving, and adapting to growth and development. Character learning can also help school administrators so that schools can improve the quality of learning for students, staff, and the school climate."

In sum, the leadership of the principals was developing students' character. This is in accordance with the results of the research, the principals are directly involved in building the students character through a variety of school activities, the principals' oversee the development of student character directly from the arrival of students to school, and with teachers work together to build the character of students through the integration of the character values.

\section{CONCLUSION}

After discussing the findings in the field and analyzing the data according to the predefined method, regarding the principal's leadership style in building the character of Primary School students, the conclusion is that the process of the leadership of SDN Kleco 1 by principal shows that the headmaster has built the character with supported by teachers, committees, and extended families; efforts made 
by the principal in building student character are the implementing by their own, implementing character of students along with teachers, and implementing character of students with staff, school committee, and parents to make school rules; the obstacles faced by the principal in building student character are the teachers are less concerned about the character building program held by the principal, not to give a reprimand or sanctions against students who are late; lack of cafeteria facilities around the school environment, the worship facilities are inadequate compared to the number of students, thus this is a problem to religious activities and also a problem for principals and teachers to develop religious souls towards students, and get less attention by parents. Here are some recommendations in the effort to build the character of students in the school, namely, school can collaborate with school committees, and other school residents to develop students' character and integrate character building with subjects taught at the time of teaching and other activities.

\section{ACKNOWLEDGMENT}

This article was supported by Overseas Seminar Scholarship Program, Directorate General of Strengthening for Research and Development, the Ministry of Research, Technology and Higher Education of the Republic of Indonesia. We thanked the University of Sebelas Maret for giving direction to always conduct research and gratitude to the head of the school where the researcher conducted the research that had given permission to study at the school, and the teachers who had worked well together.

\section{REFERENCES}

1. J. V. Tomás-Miquel, M. Expósito-Langa, and D. Nicolau-Juliá, "The influence of relationship networks on academic performance in higher education: a comparative study between students of a creative and a non-creative discipline," High. Educ., vol. 71, no. 3, pp. 307-322, 2016.

2. E. H. Robinson, K. D. Jones, and B. G. Hayes, "Humanistic Education to Character Education: An Ideological Journey," J. Humanist. Couns. Educ. Dev., vol. 39, no. 1, pp. 21-25, 2000.

3. C. R. BULACH and J. D. BUTLER, "The Occurrence of Behaviors Associated With Sixteen Character Values," J. Humanist. Couns. Educ. Dev., vol. 41, no. 2, pp. 200 214, 2002.

4. M. R. Dos Santos, "Human capital formation and criminal behavior: The role of early childhood education,” B.E. J. Econ. Anal. Policy, vol. 12, no. 1, 2012.

5. S. P. Daniati, "Natural School Culture as a Free And Fun Alternative Education in Building $t$ he Students ' Character Öğrencilerin Karakterinin İnşa Edilmesinde Ücretsiz Ve Eğlence Alternatif Eğitim Olarak Doğal Okul Kültürü,” vol. 18, no. 1, pp. 331-342, 2019.

6. K. E. Atoche-Rodríguez, A. Salazar-Pastrana, and A. M. Durán-Pérez, "Principals re-constructing their professional performance in elementary education: A participatory contribution within the educational system in Yucatan, Mexico," J. Behav. Heal. Soc. Issues, vol. 8, no. 1, pp. 17-25, 2017.

7. Q. M. Pearson and J. I. Nicholson, "Comprehensive Character Education in the Elementary School: Strategies for Administrators, Teachers, and Counselors," J.
Humanist. Couns. Educ. Dev., vol. 38, no. 4, pp. 243251, 2000.

8. J. S. Benninga, M. W. Berkowitz, P. Kuehn, and K. Smith, "Academics: What Good Schools Do there has been increasing interest in character education ( Though makers and education policy professionals , many schools among to do anything that from their focus on hesitate might detract academic The authors evidence," vol. 87 , no. 6, pp. 448-452, 2014.

9. M. W. Berkowitz, "Bringing in a new era in character education.," The science of character education. pp. 4363., 2002.

10. N. Furkan, "The Implentation of Character Education through the School Culture in Sma Negeri 1 Dompu and Sma Negeri Kilo Dompu Regency," J. Lit. Lang. Linguist., vol. 3, no. April 2009, pp. 14-44, 2014.

11. S. Rahayuningsih and Sholikhan, "Disciplinary Character Education At Early Age," IOSR J. Res. Method Educ., vol. 6, no. 5, pp. 42-49, 2016.

12. M. H. Heidari, R. A. Nowrozi, and P. Ahmadpoor, "Recognition and Applying Character Education Approaches in Schools," Rev. Eur. Stud., vol. 8, no. 3, p. $125,2016$.

13. D. Ortiz, "Research Design: Qualitative, Quantitative, and Mixed Methods Approaches [Book Review]," Qual. Res. J., vol. 6, no. 2, p. [205]-207, 2009.

14. M. Ülger, S. Yiğittir, and O. Ercan, "Secondary School Teachers' Beliefs on Character Education Competency," Procedia - Soc. Behav. Sci., vol. 131, no. 4310, pp. 442 449, 2014.

15. E. Ferdiawan and W. E. Putra, "Esq Education for Children Character Building based on Phylosophy of Javaness in Indonesia," Procedia - Soc. Behav. Sci., vol. 106, pp. 1096-1102, 2014.

16. G.-L. Lee and M. L. Manning, "Introduction: Character Education Around the World: Encouraging Positive Character Traits," Child. Educ., vol. 89, no. 5, pp. 283 285, 2013.

17. O. Shapira-Lishchinsky, "Mentors' ethical perceptions: Implications for practice," J. Educ. Adm., vol. 50, no. 4, pp. 437-462, 2012

18. J. Erwenta, L. Agung, and S. Sunardi, "The Values of Character Education in the Didong Art Performance: A Study of Enculturation Process in Gayonese Society," Int. J. Multicult. Multireligious Underst., vol. 5, no. 4, p. 196, 2018.

19. M. M. Pane and R. Patriana, "The Significance of Environmental Contents in Character Education for Quality of Life," Procedia - Soc. Behav. Sci., vol. 222, pp. 244-252, 2016.

20. C. kiu Cheung and T. yan Lee, "Improving social competence through character education," Eval. Program Plann., vol. 33, no. 3, pp. 255-263, 2010.

21. S. Gottschalk, M. M. Hake, and L. Cook-benjamin, "A Diverse Clinical-Based Practice in Teacher Education," 2015.

22. L. Nucci, D. Narvaez, and T. Krettenauer, Handbook of moral and character education. 2014.

23. B. Novick, J. S. Kress, and M. J. Elias, Building Learning Communities with Character: How to Intergrate Academic, Social, and Emotional Learning. 2002. 
International Conference on Recents Advancements in Engineering and Technology (ICRAET-18) |15th and 16th March 2019|Siddhartha Institute of Technology \& Sciences, Telangana, India.

\section{AUTHORS PROFILE}

Sri Marmoah is a lecturer at Elementary School Teacher Education at the University of Sebelas Maret. Her skill and Expertise are: primary school, educational management, teaching and learning, leadership, empowering women, literacy, etc. She has published articles on writing by educational management, primary school, women of Orang Rimba, educational policy, etc. She is a member of TEFLIN (The Association for the Teaching of English as a Foreign Language in Indonesia), Indonesian Women's Empowerment Forum, Association of Experts and Lecturers of the Republic of Indonesia, IAOI (The International Association of Organizational Innovation, USA, etc. She has many research items in the field of education sector. 